\title{
Eritema Acral Bolhoso Induzido pela Gemcitabina
}

\author{
Miguel Pinto-Gouveia', Inês Coutinho², Leonor Ramos², Maria Manuel Brites², José Carlos Cardoso², Óscar Tellechea ${ }^{3}$, Américo \\ Figueiredo ${ }^{4}$ \\ 'Médico interno do Internato Complementar de Dermatovenereologia, Serviço de Dermatologia, Centro Hospitalar e Universitário de \\ Coimbra, Portugal/Resident, Dermatology and Venereology, Centro Hospitalar e Universitário de Coimbra, Portugal \\ ${ }^{2}$ Assistente Hospitalar de Dermatologia, Serviço de Dermatologia, Centro Hospitalar e Universitário de Coimbra, Portugal/Consultant \\ of Dermatology, Dermatology Department, Centro Hospitalar e Universitário de Coimbra, Portugal \\ ${ }^{3}$ Assistente Hospitalar Graduado Sénior de Dermatologia, Serviço de Dermatologia, Centro Hospitalar e Universitário de Coimbra, \\ Portugal e Professor Auxiliar da Faculdade de Medicina da Universidade de Coimbra, Portugal/Senior Graduate Assistant in \\ Dermatology, Dermatology Department, Centro Hospitalar e Universitário de Coimbra, Portugal and Professor of Dermatology, \\ Dermatology Department, Centro Hospitalar Universitário de Coimbra, Portugal \\ ${ }^{4}$ Director do Serviço de Dermatologia, Centro Hospitalar e Universitário de Coimbra, Portugal e Professor Doutor da Faculdade de \\ Medicina da Universidade de Coimbra, Portugal/Head of Dermatology Department, Centro Hospitalar e Universitário de Coimbra, \\ Portugal and Professor of Dermatology, Dermatology Department, Centro Hospitalar Universitário de Coimbra, Portugal
}

RESUMO - O eritema acral da quimioterapia é caracterizado por áreas eritematosas e dolorosas, envolvendo predominantemente as mãos e pés, com formação de bolhas em casos severos. A gemcitabina é responsável frequentemente por reacções adversas cutâneas, embora estas sejam habitualmente transitórias e ligeiras. Relatamos o caso de um doente sob quimioterapia paliativa com gemcitabina por adenocarcinoma ductal pancreático, que desenvolveu lesões bolhosas em ambos os pés, de maiores dimensões à esquerda. A histopatologia foi consistente com eritema acral. A variante bolhosa do eritema acral da quimioterapia é uma reacção rara e, embora descrita para agentes citotóxicos estruturalmente semelhantes, não tem sido associada à gemcitabina. No doente apresentado, os antecedentes pessoais de doença arterial periférica podem ter desempenhado um papel importante na apresentação clínica final.

PALAVRAS-CHAVE - Dermatopatias Vesiculobolhosas/induzido quimicamente; Dermatoses do Pé/induzido quimicamente; Eritema/induzido quimicamente; Gemcitabina/efeitos adversos.

\section{Gemcitabine-Induced Bullous Acral Erythema}

ABSTRACT - Chemotherapy-induced acral erythema is characterized by areas of painful erythema affecting predominantly hands and feet, and in severe cases bullous lesions may develop. Gemcitabine is frequently responsible for cutaneous side effects, but these are usually mild and transient. We report a patient under palliative chemotherapy for pancreatic ductal adenocarcinoma with gemcitabine, who presented large bullous lesions on both feet, but of larger size on the left. Histopathology was consistent with acral erythema. The bullous variant of chemotherapy-induced acral eythema is a rare reaction, and although described for structurally similar cytotoxic agents, it has not been reported in association with gemcitabine. In our case, the patient's medical history of significant peripheral arterial disease may have also played an important role in the overall clinical presentation.

KEY-WORDS - Erythema/chemically induced; Foot Dermatoses/chemically induced; Gemcitabine/adverse effects; Skin Diseases, Vesiculobullous/chemically induced.

\section{INTRODUCTION}

Chemotherapeutic agents are responsible for numerous well described adverse reactions that may affect the skin, hair, mucous membranes and nails. Chemotherapy-induced acral erythema is a dose-dependent response to numerous cytotoxic agents characterized by painful well-demarcated erythematous plaques, affecting predominantly palms and soles. In severe cases, diffuse or focal blistering with possible ulceration may occur.

Gemcitabine is a nucleoside analogue with demonstrated
Correspondência: Dr. Miguel Pinto Gouveia

Serviço de Dermatologia do Centro Hospitalar e Universitário de Coimbra

Av. Bissaya Barreto, Praceta Prof. Mota Pinto - 3000-045 Coimbra, Portugal

Tel. +351 239400420 - Fax: +351 239400490

E-mail: miguelpgouveia@gmail.com
Recebido/Received

4 Abril/4 April 2016

Aceite/Accepted

19 Maio/19 May 2016 


\section{Caso Clínico}

efficacy across a range of solid tumors and has a mild toxicity profile. Cutaneous side effects are frequent, but the bullous variant of acral erythema has not yet been attributed to gemcitabine.

\section{CASE REPORT}

We report the case of a 47 year-old male, under palliative chemotherapy for pancreatic ductal adenocarcinoma. His past medical history was remarkable for insulin-dependent diabetes mellitus and for peripheral arterial disease, with an aortobifemoral bypass that had already been complicated with thrombosis of the left branch. At the time of presentation, he was in the second cycle of gemcitabine $\left(1000 \mathrm{mg} / \mathrm{m}^{2}\right)$, and had previously undergone four cycles of gemcitabine + capecitabine. Dermatology observation was requested for a 24hour history of dysesthesia and bullous lesions on both feet, of larger size on the left foot, two days after the last chemotherapy session. These bullous lesions were tense, up to $30-70 \mathrm{~mm}$ in diameter, had a citrus content and a violaceous base, with whitish and erythematous concentric halos (Fig. 1).

The patient had no other cutaneous lesions, no peripheral oedema, and no other abnormalities were noticed in the physical examination. There was no prior history of trauma or tissue injury.
Complete blood count showed haemoglobin of $11.5 \mathrm{gr} /$ $\mathrm{dL}$, leucocytes $5.3 \times 10^{9} / \mathrm{L}$ (57\% of neutrophils) and thrombocythopenia with platelets $82 \times 10^{9} / \mathrm{L}$. Biochemistry panel revealed C-reactive protein $3.5 \mathrm{mg} / \mathrm{dL}$, creatinine $0.75 \mathrm{mg} /$ $\mathrm{dL}, \mathrm{HbAlc} 9.8 \%$ with no other particular abnormalities. Anti-nuclear antibodies and anti-neutrophil cytoplasmatic antibodies were negative.

Cultures of blood, urine and exudate from bulla were negative.

Biopsy of a bullous lesion revealed necrosis of the superficial layers of the epidermis, single apoptotic keratinocytes in the lower layers, and formation of small multifocal intraepidermal or subepidermal vesicles. On the upper dermis, congested and thrombosed capillaries were seen. Eccrine glands were hyalinized and distorted, suggesting necrosis. The inflammatory infiltrate was mild, consisting predominantly of sparse interstitial neutrophils. These features were highly suggestive of a reaction to chemotherapy, conforming to the bullous variant of acral erythema (Fig. 2).

After a slight improvement with high potency topical corticosteroids, there was clear worsening after a new gemcitabine infusion 12 days after the previous administration, with ulceration and necrotic eschars in the previously affected locations (Fig. 3a).
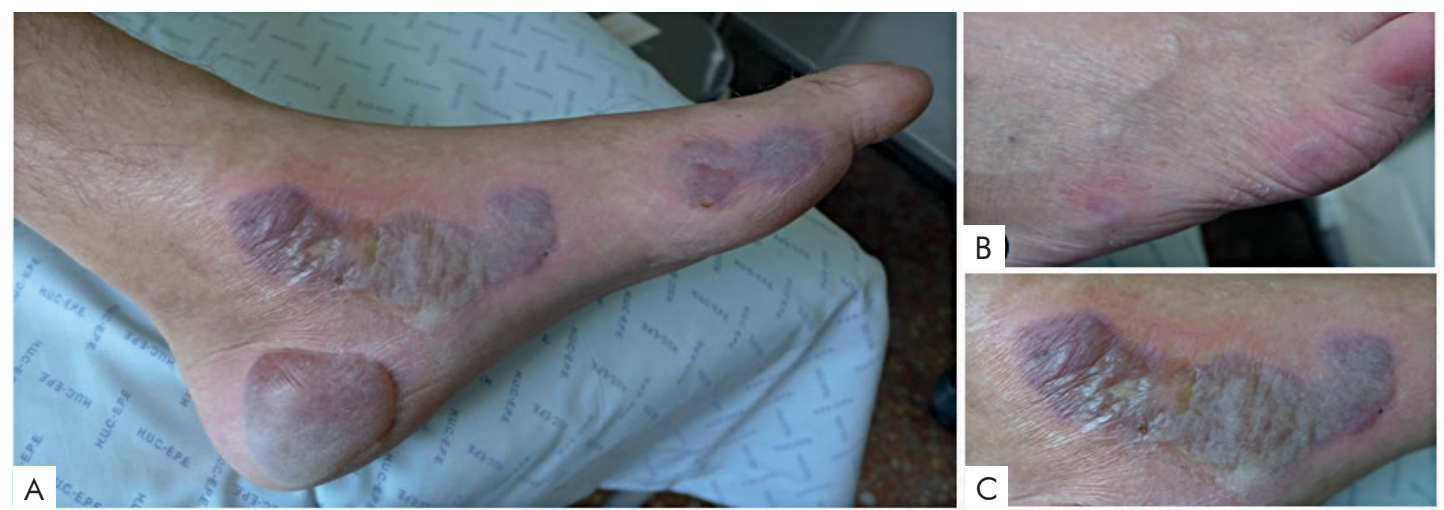

Figure 1 - Large bullous lesions on the left foot, 2 days after second cycle of gemcitabine (A). Smaller bullous lesions on the right foot (B). Detail of a bullous lesion $(\mathbf{C})$.
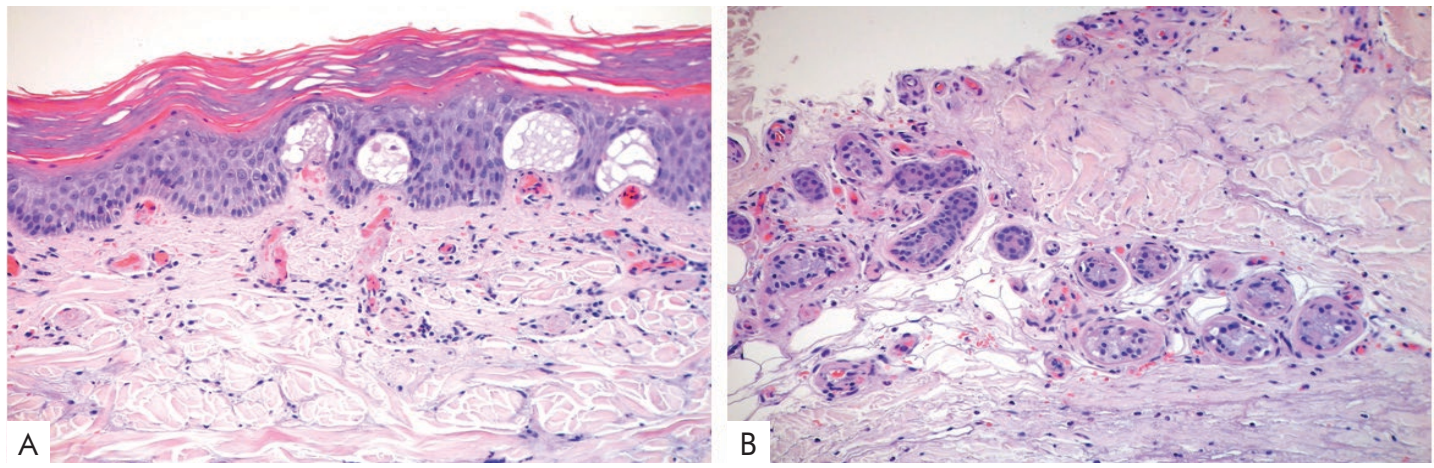

Figure 2 - Dyskeratotic keratinocytes in the upper layers of the epidermis, subepidermal vesiculation and congested capillaries (A). Paleness and hyalinization of the sweat gland coils suggesting early necrosis (B). 


\section{Caso Clínico}
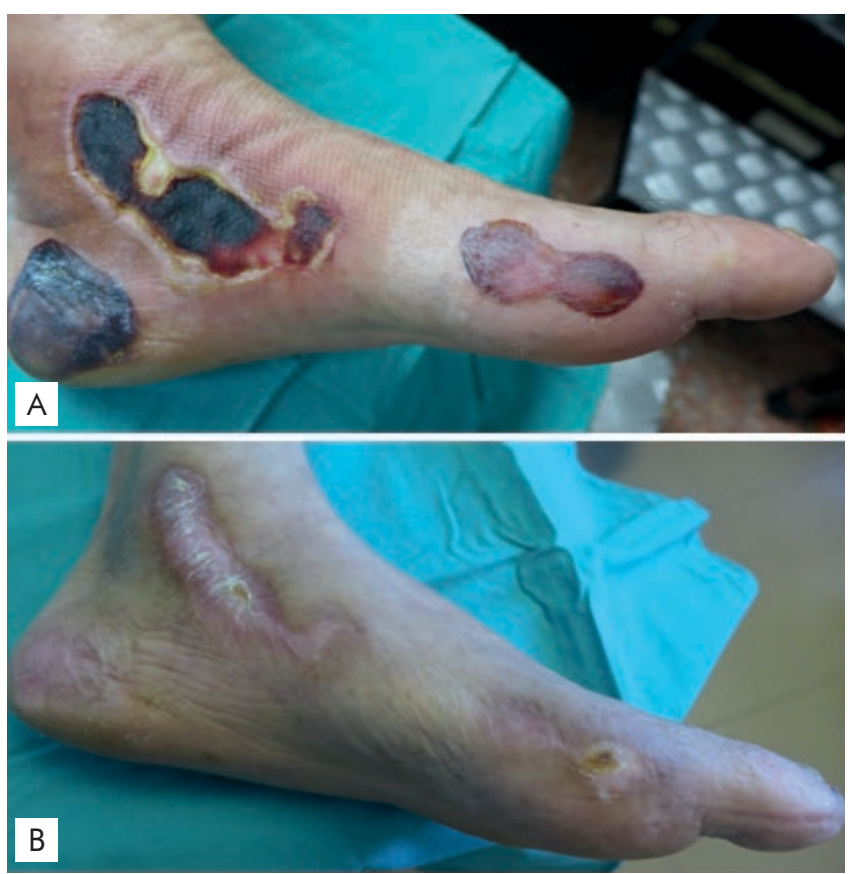

Figure 3 - Necrotic eschars after the third cycle of gemcitabine $(\mathrm{A})$ Complete ulcer healing 4 months after initial presentation (B).

The anti-neoplastic treatments were suspended for 49 days, leading to a significant improvement of the ulcerations.

Although there was a possibility of clinical worsening, considering the benefits of continuing with chemotherapy, the patient was started again on gemcitabine maintaining the same dose $\left(1000 \mathrm{mg} / \mathrm{m}^{2}\right)$ and without any kind of pre-medication. He concluded the $4^{\text {th }}$ and $5^{\text {th }}$ cycle of his chemotherapy, and kept a good evolution with proper wound care, which culminated in complete ulcer healing approximately 4 months after the initial presentation (Fig. 3b).

\section{DISCUSSION}

We report a case of acral erythema induced by gemcitabine, with a striking presentation consisting of large bullous lesions associated with dysesthesia. The Naranjo probability score $^{1}$ showed a probable relationship between gemcitabine and the cutaneous lesions (calculated score =6), and this hypothesis was strongly supported by the histopathology. Other differential diagnosis like auto-immune diseases or acral vasculitis were considered less probable. Regarding auto-immune diseases there was no background, additional cutaneous or systemic manifestations, as well as no serologic data in favor of this hypothesis. Considering acral vasculitis (paraneoplastic syndrome), there was no Raynaud phenomenon or other signs of ischemia (acrocyanosis, digital gangrene or pain) that are usually associated. Improvement is frequently only seen after control of the primary disease, ${ }^{2}$ which was not the case in our patient. The histopathology was also not in favor of these diagnosis has it showed only thrombosed capillaries, with no signs of vasculitis, namely fibrinoid necrosis, perivascular inflammatory infiltrate or karyorrhexis.

Acral erythema is a common adverse reaction to chemotherapy, but is still a matter of some confusion for clinicians. The heterogeneous clinical presentations due to the various grades of severity ${ }^{3}$ and sites involved, in addition to the different histologic findings (some more prominent in eccrine glands, while others more pronounced in the epidermis), may explain its numerous designations in the literature (e.g. hand-foot syndrome, Burgdorf reaction, eccrine squamous syringometaplasia, epidermal dysmaturation, palmoplantar erythrodysestesia and neutrophilic eccrine hidradenitis). More recently the designation toxic erythema of chemotherapy was proposed as an encompassing term..$^{4,5}$

Typically the full blown picture develops after several cycles of chemotherapy but the clinical course is difficult to predict as it may worsen from cycle to cycle, while others may heal during therapy-free intervals, and some may even tolerate further treatments without any recurrence. ${ }^{6}$

The severe bullous variant of chemotherapy-induced acral erythema is a rare reaction, and although described for structurally similar cytotoxic agents like cytarabine, ${ }^{7}$ it has not been reported in association with gemcitabine. Other agents in relation with this variant include methotrexate, cyclophosphamide and vincristine. ${ }^{8}$

With the introduction of new targeted cancer therapies, several new cutaneous drug reactions have been described. The hand-foot-skin reaction has been described in association with the multikinase inhibitors (sorafenib and sunitinib) and has similarities with acral erythema from conventional chemotherapy, but is distinguished clinically by localized lesions (instead of diffuse involvement), particularly in friction areas, that rapidly become hyperkeratosic. ${ }^{9,10}$

Gemcitabine's cutaneous toxicity is reported in $24.8 \%$ of patients, ${ }^{11}$ predominantly maculopapular rash, alopecia and mucositis, which are usually mild and transient. However there are also several adverse reactions that have been seldom reported, including entities within the spectrum of acral erythema, such as fixed erythrodysaethesia ${ }^{12}$ and recurrent toxic erythema. ${ }^{13}$

Recently some authors ${ }^{14,15}$ reported on gemcitabine-induced bullous lesions, although apparently not in the context of acral erythema. In both cases, the histopathology did not show any aspects suggestive of a toxic reaction.

The pathomechanism of acral erythema is not completely elucidated, but histological investigations suggest a toxic effect on the basal keratinocytes and upper dermal vessels. ${ }^{16}$ In our case the underlying vascular disease may have also played an important role in the overall clinical presentation. According to some authors, ${ }^{17}$ gemcitabine-induced reactions may be caused by accumulation of the drug in the skin and subcutaneous tissue, and since this type of reaction seems to be dose-dependent, the vasculopathy could have increased local toxicity. In this sense, we speculate that the suspension of the drug may have permitted the elimination of the drug and its metabolites leading to improvement of the lesions, while the later reintroduction did not originate enough local toxicity to cause clinical worsening.

Gemcitabine was also associated with cases of vascular toxicity, namely necrotizing vasculitis and digital ischemia. ${ }^{18,19}$ Therefore it is recommended caution while using gemcitabine in patients with micro or macroangiopathy and with 
auto-immune diseases, since the risk of digital necrosis is higher in these cases. ${ }^{20}$ Additionally, according to some authors, it is also possible that vascular aggression plays a part in acral erythema, and in fact we cannot exclude a contribution of the vascular thrombosis observed in our case, but the overall presentation is considered to result most likely from the epidermal insult by the gemcitabine. ${ }^{13}$

In the management of acral erythema, dose modification, systemic or local symptomatic approaches can be used. ${ }^{21}$ Dose reduction or interruption of the therapy is often necessary initially, and if acral erythema repeatedly recurs even more severely, dose adjustment or discontinuation of therapy may be inevitable. Pyridoxine has also been found beneficial and high-potency corticosteroids have been proven effective as topical therapy. ${ }^{16}$ The use of pre-medication with dexamethasone, before gemcitabine administration was also described in the literature, although mainly in the context of gemcitabine-induced maculopapular exanthema. ${ }^{22}$

As in our case, strict cooperation between dermatologist and oncologist is advisable, in order to wage the benefits and counterparts of suspending the chemotherapy.

We presented an impressive gemcitabine-induced case of acral erythema with bullous lesions, in which the severity and asymmetry were possibly due to the patient's history of significant peripheral arterial disease.

Conflitos de interesse: Os autores declaram não possuir conflitos de interesse. Suporte financeiro: $O$ presente trabalho não foi suportado por nenhum subsídio ou bolsa. Confidencialidade dos Dados: Os autores declaram ter seguido os protocolos do seu centro de trabalho acerca da publicação dos dados de doentes.

Conflicts of interest: The authors have no conflicts of interest to declare. Financing Support: This work has not received any contribution, grant or scholarship. Confidentiality of data: The authors declare that they have followed the protocols of their work center on the publication of data from patients.

\section{REFERENCES}

1. Naranjo CA, Busto U, Sellers EM, Sandor P, Ruiz I, Roberts EA, et al. A method for estimating the probability of adverse drug reactions. Clin Pharmacol Ther. 1981; 30:239-45.

2. Rodriguez Martin AM, Guirao Arrabal E, Jimenez Puya R, Velez Garcia-Nieto A. Paraneoplastic Acral Vascular Syndrome. Actas Dermosifiliogr. 2015; 106:601-2.

3. Lotem M, Hubert A, Lyass $O$, Goldenhersh MA, Ingber A, Peretz T, et al. Skin toxic effects of polyethylene glycol-coated liposomal doxorubicin. Arch Dermatol. 2000; 136: 1475-80.

4. Bolognia JL, Cooper DL, Glusac EJ. Toxic erythema of chemotherapy: a useful clinical term. J Am Acad Dermatol. 2008; 59:524-9.

5. Marques Pinto G. Medicamentos que induzem ou agravam doenças cutâneas crónicas. Trab Soc Port Dermat Venereol. 2010; 68:11-44.

6. Revenga Arranz F, Fernandez-Duran DA, Grande C,
Rodriguez Peralto JL, Vanaclocha Sebastian F. Acute and painful erythema of the hands and feet. Acral erythema induced by chemotherapy. Arch Dermatol. 1997; 133:499500, 2-3.

7. Azurdia RM, Clark RE, Friedmann PS. Chemotherapy-induced acral erythema (CIAE) with bullous reaction. Clin Exp Dermatol. 1999; 24:64-6.

8. Waltzer JF, Flowers FP. Bullous variant of chemotherapy-induced acral erythema. Arch Dermatol. 1993; 129:435.

9. Balagula Y, Lacouture ME, Cotliar JA. Dermatologic toxicities of targeted anticancer therapies. J Support Oncol. 2010; 8:149-61.

10. Robert C, Sibaud V, Mateus C, Cherpelis BS. Advances in the management of cutaneous toxicities of targeted therapies. Semin Oncol. 2012; 39:227-40.

11. Aapro MS, Martin C, Hatty S. Gemcitabine--a safety review. Anticancer Drugs. 1998; 9:191-201.

12. Chu $\mathrm{CY}$, Yang $\mathrm{CH}$, Chiu HC. Fixed erythrodysaesthesia plaque due to gemcitabine and epirubicin treatment. Acta Derm Venereol. 2002; 82:147-8.

13. Li J, Ko CJ, Saif MW. Recurrent cutaneous toxic erythema induced by gemcitabine in a patient with pancreatic cancer. Cutan Ocul Toxicol. 2009; 28:144-8.

14. Imen A, Amal K, Ines Z, Sameh el F, Fethi el M, Habib $G$. Bullous dermatosis associated with gemcitabine therapy for non-small-cell lung carcinoma. Respir Med. 2006; 100:1463-5.

15. Jidar K, Ingen-Housz-Oro S, Beylot-Barry M, Paul C, Chaoui D, Sigal-Grinberg M, et al. Gemcitabine treatment in cutaneous T-cell lymphoma: a multicentre study of 23 cases. Br J Dermatol. 2009; 161:660-3.

16. Janusch $M$, Fischer $M$, Marsch W, Holzhausen HJ, Kegel T, Helmbold P. The hand-foot syndrome--a frequent secondary manifestation in antineoplastic chemotherapy. Eur J Dermatol. 2006; 16:494-9.

17. Brandes A, Reichmann U, Plasswilm L, Bamberg M. Timeand dose-limiting erysipeloid rash confined to areas of lymphedema following treatment with gemcitabine--a report of three cases. Anticancer Drugs. 2000; 11:15-7.

18. Voorburg AM, van Beek FT, Slee PH, Seldenrijk CA, Schramel FM. Vasculitis due to gemcitabine. Lung Cancer. 2002; 36:203-5.

19. Venat-Bouvet L, Ly K, Szelag JC, Martin J, Labourey JL, Genet D, et al. Thrombotic microangiopathy and digital necrosis: two unrecognized toxicities of gemcitabine. Anticancer Drugs. 2003; 14:829-32.

20. Dasanu CA. Gemcitabine: vascular toxicity and prothrombotic potential. Expert Opin Drug Saf. 2008; 7:703-16.

21. Scheithaver W, Blum J. Coming to grips with hand-foot syndrome. Insights from clinical trials evaluating capecitabine. Oncology. 2004; 18:1161-8, 73; discussion 73-6, 81-4.

22. Kanai $M$, Matsumoto $S$, Nishimura $T$, Matsumura $Y$, Hatano $E$, Mori $A$, et al. Premedication with 20 mg dexamethasone effectively prevents relapse of extensive skin rash associated with gemcitabine monotherapy. Ann Oncol. 2010; 21:189-90. 